\title{
Ny rammeplan for barne- hagens innhold og oppgaver
}

Ny rammeplan for barnehagens innhold og oppgaver trådte i kraft 1.august. Prosessen mot ny rammeplan startet som en revisjon igangsatt av kunnskapsminister Kristin Halvorsen (SV), men ble sluttført som en total nyskriving ledet av kunnskapsminister Torbjørn Røe Isaksen (H). Departementets intensjoner med den nye planen var blant annet at barnehagens plikter og oppgaver skulle formuleres tydeligere. De utarbeidet en mer kortfattet plan ved å redusere mengden prosatekst, og justerte den språklige formen i forskriftsretning. Innføring av målformuleringer i tilknytning til barnehagens helhetlige arbeid med omsorg, lek, laring og danning ble videreført fra Halvorsens arbeid med revisjon. Departementet uttrykte også mål om at planen skulle fungere som styringsdokument.

Tekstene som følger viser både tema som ble mye debattert $i$ høringsprosessen, og andre tema som ble viet mindre oppmerksomhet, men som kan vare desto viktigere a tematisere i implementeringsfasen. Tekstene handler om ansvar og roller, barnehagelœrerens metodefrihet og rommet for skjønnsutøvelse, barnehagens helhetlige tilncerming til det pedagogiske arbeidet, barnehagens verdigrunnlag og rammeplanens funksjon. Forfatterne er tilknyttet ulike institusjoner.

\section{Et viktig verdidokument \\ Av MoRTEN SolHeIM, seniorrådgiver i Utdanningsforbundet. \\ E-post: morten.solheim@utdanningsforbundet.no}

Etter en lang prosess med stort engasjement i barnehagesektoren leverte Utdanningsforbundet et omfattende høringssvar til regjeringen om deres utkast til ny Rammeplan for barnehagen. Her følger to momenter som var viktige for oss.

\section{Samarbeidet Mellom hJEM Og BARNehAgE}

I Barnehagelovens §1 Formål heter det at «Barnehagen skal i samarbeid og forståelse med hjemmet ivareta barnas behov for omsorg og lek, og fremme læring og danning som grunnlag for allsidig utvikling. >

Samarbeidet mellom hjem og barnehage er et av de viktigste vilkårene for et godt barnehagetilbud. Fra Utdanningsforbundets side var det derfor viktig å styrke en ny rammeplan, for å styrke det rettslige grunnlaget for samarbeidet mellom hjem og barnehage. I høringsutkastet ble dette imidlertid løst på en slik måte at kapittelet fremsto mer som en beskrivelse av foreldres rettigheter enn en beskrivelse av samarbeidet mellom hjemmet og barnehagen. Enkelte av 
formuleringene var også problematiske med tanke på hensynet til personopplysningsloven.

Barnehagen er første frivillige del av utdanningsløpet. Som utdanningsinstitusjon har barnehagen derfor et lovmessig nedfelt formål og innhold. Hvordan dette formålet og innholdet løses, er det viktig at barnehagen involverer hjemmet i. Samtidig er det et kollektivt element i det å tilby den samme utdanningen til alle barn. Dette betyr selvsagt ikke at tilbudet aldri skal tilpasses det enkelte barn, men det er forskjell på en form for foreldremedvirkning som bidrar til at tilbudet best tilpasses alle barn, og en form for foreldremedvirkning med mulighet for at det åpnes for et mer individuelt tilpasset tilbud. Utdanningsforbundet løftet gjennom sitt høringssvar frem betydningen av at et samarbeid mellom barnehage og hjem må være forpliktende fra begge sider, uten å åpne for en praksis som bryter med de verdiene som ligger i barnehagens formålsparagraf.

Et annet element $i$ høringsutkastet som vi så med bekymring på, var åpningen for en mer utbredt dokumentasjonspraksis og $\emptyset \mathrm{kt}$ overføring av skriftlig informasjon mellom hjem og barnehage. I høringsutkastet fra regjeringen het det at «På individnivå skal barnehagen legge til rette for at foreldrene og barnehagen jevnlig kan utveksle observasjoner og vurderinger knyttet til enkeltbarnets helse, trivsel, erfaringer, utvikling og læring». Utdanningsforbundet mente en slik omtale av utveksling av observasjoner og vurderinger kunne forstås som plikt til utveksling av skriftlig dokumentasjon. Dette kan skape unødige misforståelser og konflikter mellom personalet og foreldre. I stedet mener Utdanningsforbundet at samarbeidet må handle om å diskutere eller drøfte barnas trivsel og utvikling, selvsagt basert på løpende observasjoner og vurderinger av barnets trivsel og utvikling. Vi foreslo derfor å endre det nevnte avsnittet slik: «På individnivå skal barnehagen legge til rette for at foreldrene jevnlig kan diskutere barnets trivsel og utvikling med det pedagogiske personalet. (...) Barnehagens personale skal ta hensyn til foreldrenes synspunkter og foreldrene skal gis innflytelse på det pedagogiske tilbudet til sitt barn.»

I den ferdigstilte rammeplanen er forpliktelsen om samarbeidet mellom hjem og barnehage styrket. Samtidig er noen av formuleringene som omhandler utveksling av observasjoner og vurderinger av en slik karakter at de kan åpne for en mere utbredt dokumentasjonspraksis knyttet til enkeltbarn. Fremover blir det viktig for Utdanningsforbundet å fortsatt jobbe for en vettug dokumentasjonspraksis i barnehagene, en som ikke er i strid med personvernloven og som ivaretar barns og foreldres rettigheter på en god måte.

\section{Ansvar og profesjonelt skjønn}

Et svært viktig poeng for Utdanningsforbundet og for barnehagelærerprofesjonen var å ivareta barnehagelærerens ansvar og mulighet for profesjonell 
skjønnsutøvelse. I høringsutkastet fantes formuleringer som kunne bidratt til å begrense barnehagelærerens mulighet til å fatte gode beslutninger. For Utdanningsforbundet er det viktig at de som har kompetanse om små barn, styrer og barnehagelærer/pedagogisk leder, og som daglig står i arbeid i direkte møte med barna, er de som gis ansvar for å følge opp barnegruppa og enkeltbarn, selvsagt i nær forståelse med barnets hjem. I utkastet til ny rammeplan fremkom dette ansvaret noe utydelig, og beslutningsansvaret ble tilsynelatende lagt på eiernivå.

Utdanningsforbundet er godt fornøyd med formuleringen i den ferdigstilte rammeplanen hvor det heter: «Pedagogisk leder er gitt ansvaret for å iverksette og lede det pedagogiske arbeidet, i tråd med godt faglig skjønn.»

\section{VEIEN VIDERE}

Utdanningsforbundets innspill $\mathrm{i}$ høringsprosessen har, sammen med mange andre instansers innspill, bidratt til at den ferdigstilte rammeplanen for barnehagen er blitt et godt arbeidsverkt $\emptyset \mathrm{y}$ for barnehagelærerprofesjonen, styringsverktøy for eierne og informasjon til foreldre og foresatte. Verdiene i formålsparagrafen kommer tydelig frem, og fortsatt har leken en fremtredende plass $i$ et av barnehagens viktigste styringsdokumenter. Som med alle forskrifter er det også i rammeplanen flere aspekter som gir rom for fortolkning, og som vil føre til diskusjoner i tiden fremover. Vi tror Rammeplanen for barnehagen vil gi gode føringer for arbeidet $\mathrm{i}$ den enkelte barnehage, og vi vil fortsette å bidra med våre fortolkninger av dette viktige verdidokumentet, når dokumentet nå implementeres.

\section{Roller og ansvar}

Av Marit BøE og Karin Hognestad, Høgskolen i Sørøst-Norge. E-post: Karin.Hognestad@usn.no og Marit.Boe@usn.no

Ett av områdene Høgskolen i Sørøst-Norge (HSN) kommenterte på i høringssvaret, var rammeplanens formuleringer om roller og ansvar, der vi påpekte svakheter blant annet ved omtalen av barnehagelærerprofesjonens ansvar for det pedagogiske arbeidet. I høringssvaret skrev vi følgende:

Kapittel 7 (6) om Ansvar og roller presiserer de ulike rollene og ansvarsområdene $i$ barnehagen, og danner grunnlaget for å si noe om oppgavene og kompetansen som forutsetning for lesing og forståelse av rammeplanens videre innhold.

HSN mener imidlertid generelt at rammeplanen bør være tydeligere når det gjelder barnehagelcererprofesjonens faglige og etiske forpliktelser og ansvar for det pedagogiske arbeidet. For å skape en god progresjon i og øke lesbarheten av dokumentet, 
foreslår vi at kapittelet flyttes frem, gjerne som kapittel 2. Ved å plassere dette tidlig $i$ Rammeplanen, vil det tydeliggjøre hvem teksten snakker til, synliggjøre menneskene $i$ organisasjonen og det ansvaret som knyttes til de ulike ledernivåene. For å synliggjøre alle kategorier av ansatte i barnehagen, foreslä vi at det formuleres egne avsnitt for hhv stillingen barnehagelareren (som ikke er pedagogisk leder) og øvig personale.

I høringsdokumentets kapittel om Ansvar og roller er det barnehageeier, styrer og pedagogisk leder som beskrives, men vi savner at også rollen som barnehagelarer (som en organisatorisk posisjon) benevnes og dennes medansvar vektlegges. Mange barnehager har allerede flere pedagoger pr. avdeling, og når målet for pedagogbemanningen er $50 \%$ innen 2020, bør denne rollens ansvar allerede nå komme frem i barnehagens styringsdokument. Det bør derfor synliggjøre hvilke forventninger det bør stilles til stillingen barnehagelarer $i$ en fremtidig organisasjon.

Regjeringen foreslår å fjerne setningen om metodefrihet: «Den enkelte barnehage står fritt til å velge metoder og omfang ut fra lokale forutsetninger og behov. » Også $i$ skolen har metodefriheten vart under press, men er nå sikret gjennom stortingsflertallets beslutning. Formuleringen fra RP 11 bør tas inn igjen.

Det står i teksten at barnehageeier skal vektlegge de ansattes faglige og pedagogiske vurderinger. Her bør det tydeligere komme frem at det er den barnefaglige kompetansen som skal lyttes til og at det er barnehagelorernes fagkunnskap om barn som eier må ta hensyn til i sin styring, altså et skille mellom pedagogisk leder og øvrige ansatte. Det er vesentlig å få fram at eier aktivt «skal vektlegge», og ikke det mer passive «vektlegger».

I rammeplanen slik den er vedtatt er kapittelet om Ansvar og Roller flyttet frem. Her er det også lagt til en formulering som presiserer at barnehagelærere er den profesjonen som utdannes spesielt for å kunne ivareta barnehagens oppgaver. Rammeplanen tydeliggjør derfor at barnehagelærere har ulike roller og ansvar i barnehagen. Barnehagelærerrollen beskrives under kapittelet om roller og ansvar, og gir en tydeligere differensiering av roller og ansvar som vil skape variasjoner av lederposisjoner og barnehagelærere uten lederposisjoner. Dette gjør at barnehagelærerens plass i personalgruppen blir tydeligere i forhold til barnehagelærerprofesjonens faglige og etiske forpliktelser og ansvar for det pedagogiske arbeidet. Den nye Rammeplanen inneholder likevel ikke en presisering av roller og ansvar når det er to eller flere barnehagelærere pr avdeling eller gruppe. Det blir derfor opp til den enkelte barnehage å fordele ansvar og oppgaver. En tydeligere nyansering i oppgaver og ansvar kan på sikt føre til økt spesialisering i yrkesutøvelsen. Dette kan samtidig utfordre målet om å styrke en felles profesjonsidentitet hvor det som er felles for de ulike rollene, blir tydeligere enn det som oppleves i dag. 


\section{Hva skal barnehagen med et verdigrunnlag?}

Av GunNAR HAALAND, førsteamanuensis ved Institutt for barnehagelorerutdanning, HiOA. E-post: gunnar.haaland@hioa.no

Med den nye rammeplanen for barnehagen står vi uten en forskriftsfestet tolkning og tydeliggjøring av barnehagelovens verdibestemmelse.

Samtidig med at den såkalt «kristne formålsparagrafen» trådte i kraft i 1984, ble følgende forskrift fastsatt:

Barnehagen skal bygge sin virksomhet på de etiske grunnverdiene som er forankret $i$ kristendommen. Den etiske veiledningen barnehagen gir, må ta hensyn til barnas alder og modenhet, og deres hjemmemiljø. Barnehagen skal formidle sentrale kristne tradisjoner slik de bl.a. kommer til uttrykk ved de store kristne høytider. (§ 1.2)

Denne teksten ble utvidet og nyansert i den første rammeplanen for barnehagen av 1995. I rammeplanen av 2006 ble teksten - og dermed den autoritative tolkningen av lovteksten - endret vesentlig: Det handlet ikke lenger om kristne høytider og tradisjoner, kun om felles etiske grunnverdier. Dermed var den «kristne formålsparagrafen» ikke lenger særlig kristen, og slik sett foregriper 2006-rammeplanen den nåværende verdibestemmelsen i barnehageloven (vedtatt 2008, trådt i kraft 2010).

En tilsvarende presisering av formålsparagrafens verdibestemmelse savnes i rammeplanen av 2011. Det knyttes noen kommentarer til lovformuleringene «grunnleggende verdier i kristen og humanistisk arv og tradisjon» og «verdier som kommer til uttrykk i ulike religioner og livssyn», men det presenteres ingen tydelig tolkning av den nye verdibestemmelsen i loven.

$\AA$ levere en slik tolkning er krevende, fordi gjeldende verdibestemmelse er et kompromiss der ulike partier og andre aktører hadde og har ulike tolkninger:

1 Hva er forholdet mellom «kristen» og 《humanistisk» arv og tradisjon? Dreier det seg om to forskjellige tradisjoner, representert ved henholdsvis kristne trossamfunn og Human-Etisk Forbund? Eller forstås humanismen som innvevet i kristen arv og tradisjon? Eller begge deler?

2 Hva er forholdet mellom «kristen og humanistisk arv og tradisjon», «andre religioner og livssyn» og «menneskerettighetene»? Sammenlignet med Bostad-utvalgets og den rødgrønne regjeringens forslag til lovtekst løftet Stortinget «kristen og humanistisk arv og tradisjon» frem i teksten og ga med dette en større tyngde til denne frasen. Noen har derfor ment at kris- 
tendommen fremdeles har en form for forrang. Andre har argumentert for at forankringen i menneskerettighetene må være det mest tungtveiende.

Dette er to av flere viktige tolkningsspørsmål som rammeplanen burde adressert. I stedet for å tydeliggjøre der 2011-planen var utydelig, virker det som om departementet nærmest har kapitulert. Den nye rammeplanen forholder seg i minimal grad til de konkrete formuleringene i formålsparagrafens verdibestemmelse. Dette representerer altså et brudd på en tradisjon som går helt tilbake til 1984. I denne forbindelse har to vesentlige ting skjedd:

1 Den nye rammeplanen utnytter ikke formålsparagrafens verdibestemmelse til å løfte frem kristendommen og andre religioner og livssyn som kilder for etiske grunnverdier, og mangler en prinsipiell grenseoppgang for barnehagens befatning med religionsfeltet, slik vi tidligere har hatt i formuleringen «Opplæring til tro er hjemmets ansvar».

2 Barnehagens etiske verdigrunnlag er gjort mindre forpliktende. Tidligere het det at barnehagen skal bidra til at barna «tilegner seg samfunnets grunnleggende normer og verdier». I stedet for et slikt bredt danningsperspektiv er barnehagens verdiformidling nå redusert til noe kognitivt: Barnehagen skal bidra til at barna «får kjennskap til, forstår og reflekterer over grunnleggende normer og verdier».

Disse to kritiske anliggendene ble spilt inn i høringsprosessen av henholdsvis meg selv og fakultetet mitt, men ingen av dem ble fulgt opp.

Det kan imidlertid virke som om departementet i siste runde har gjort et fors $\emptyset \mathrm{k}$ på å koble rammeplanen litt tettere på lovteksten. Nå heter det at barnehagen skal bidra til at barna «får kjennskap til grunnleggende verdier i kristen og humanistisk arv og tradisjon og blir kjent med religioner og livssyn som er representert i barnehagen» i stedet for høringsnotatets «blir kjent med kristen tro og kulturarv og andre religioner og livssyn som er representert $i$ barnehagen og i lokalsamfunnet». Dette er ikke en endring til det bedre. Her synes det som om «grunnleggende verdier» a) refererer til noe annet enn de konkrete, etiske grunnverdiene som loven nevner, og b) knyttes eksklusivt til «kristen og humanistisk arv og tradisjon», i strid med den bredere og mer pluralistiske forankringen av de «grunnleggende verdier» som lovteksten sikrer.

Etter at den nye rammeplanen var fastsatt, fikk vi en valgkamp der kulturarv og grunnverdier noe uventet kom i fokus. Diskusjonen var imidlertid mer slagordpreget enn innsiktsfull. Den som ønsker å sette slike temaer på den barnehagefaglige dagsorden, får dessverre liten drahjelp fra rammeplanen. 


\title{
Samfunnsmandat og helhetlig forståelse av læring
}

\author{
Utklipp fra høringssvar fra Berit Bae, \\ BERIT BAE, professor emerita, Høgskolen i Oslo og Akershus. E-post: berit.bae@hioa.no
}

$\AA$ legge vekt på en helhetlig forståelse av læring - som integrerer lek-omsorg og læring er en del av det brede samfunnsmandatet for norske barnehager. Det sies under verdigrunnlag at lek-omsorg-læring og danning skal sees i sammenheng. Dette er imidlertid ikke tydelig fulgt opp utover i planen, hverken under barnehagens formål og innhold eller under beskrivelse av fagområdene. Dermed blir ikke rammeplanen som helhet et tydelig og velegnet arbeidsredskap når det gjelder hvordan barnehagepersonalet skal arbeide for å realisere et helhetlig læringssyn.

For å understreke en helhetlig tilnærming kunne det f.eks. i kapittel 3 under omsorg vært et kulepunkt at personalet skal vise omsorg for barn som faller utenfor i leke- eller læringssituasjoner. Og under avsnittet om barns behov for lek hadde det vært relevant å nevne at personalet skal kunne ta imot barns lekende innspill i omsorgssituasjoner som f.eks. stell, måltid, påkledning o.l. Under avsnittet om læering hadde det også vært på sin plass å peke på at personalet skal kunne møte barns lekende og humoristiske ytringer og samspill i læringssituasjoner.

I praktisk arbeid i barnehager, enten det er i hverdagsaktiviteter eller i arbeid med fagområder, skal altså omsorg og lek integreres i barnas aktive deltagelse i læringsprosesser. Det som er underkommunisert i høringsutkastet, særlig i den delen som handler om fagområder, er at barn lærer mye gjennom lek, og at hverdagsaktiviteter som måltid, påkledning, stellesituasjoner kan romme viktige læringsprosesser. Når en leser det som står under de ulike fagområdene, ser en at disse er meget ulikt formulert. F.eks. så nevnes lek bare sporadisk, og omsorg omtales ikke i det hele tatt. Dette er klart mangelfullt i forhold til oppfølging av det helhetlige læringssynet som omtales under barnehagens verdigrunnlag.

Barnas aktive medvirkning og læring via sansemessige-kroppslige erfaringer kunne også vært mye tydeligere omtalt. Formuleringer brukt under mange av fagområdene virker lite dekkende og velegnet til å beskrive små barns læringsprosesser, særlig tatt i betraktning at en stor andel av barnehagebarna er mellom 1 og 3 år. Som eksempel kan formuleringer som at barn skal få kjennskap til ,.. få innsikt $i$... få forståelse for med fordel skiftes ut med formuleringer som ligger nærmere små barns læringsmåter, som f.eks at barn skal erfare ..., medvirke/delta ..., utforske ..., undre seg ..., observere .... o.l.

Barnehager i dagens samfunn får mange tilbud om materiell og program rettet mot arbeid med fag, og en del barnehageeiere pålegger barnehagene sine å bruke spesielle metodiske tilnærminger i arbeid med barns læringspro- 
sesser. Mange av disse programmene /metodetilnærmingene bygger på andre pedagogiske forutsetninger og et annet syn på barn enn det verdigrunnlaget som gjelder for norske barnehager. Beskrivelser og prosessmål under fagområdene som har tydelig sammenheng med verdigrunnlaget for barnehagene, kan gjøre det lettere for styrere/barnehagelærere/pedagogiske ledere å vurdere om metoder og faglige tilnærminger de tilbys/pålegges, går på tvers av barnehagens brede samfunnsmandat og helhetlige læringssyn eller ikke.

(...) Hvis rammeplanen skal være et velegnet arbeidsdokument for barnehagepersonalet til å arbeide i tråd med verdigrunnlaget, er det nødvendig å se kritisk på om framstillingen fanger opp/gjenspeiler den helhetlige læringsforståelsen og barns rett til å medvirke aktivt i egne lærings- og utviklingsprosesser. Jeg savner bedre samsvar mellom det som sies under verdigrunnlag og hvordan dette skal følges opp i det praktiske arbeidet, både i hverdagssituasjoner og under arbeid med fagområdene.

\section{Det rammeplanen ikke sier \\ Av MARTE ERIKSEn, barnehagerådgiver ved IKO - Kirkelig pedagogisk senter. E-post: marte.eriksen@iko.no}

Et av spørsmålene departementet $\emptyset$ nsket å få belyst av høringsinstansene var om rammeplanen ivaretok barnehagens brede samfunnsmandat. Barnehageloven §1 1.ledd kan sees på som et ekstrakt av det brede samfunnsmandatet. Her sier loven at barnehagen i nær forståelse med hjemmet skal ivareta barns behov for omsorg og lek og fremme læring og danning som grunnlag for allsidig utvikling. Videre fastsetter lovteksten de verdiene barnehagen skal bygge arbeidet på, og hvor disse verdiene har sin forankring. I følge Gunnar Haalands tekst ovenfor, verken tolker eller tydeliggjør rammeplanen barnehagens verdigrunnlag. Slik sett kan det være tilfelle at rammeplanen ikke i tilstrekkelig grad ivaretar barnehagens brede samfunnsmandat, fordi den ikke bidrar til å klargjøre hvordan ulike bestemmelser i barnehageloven skal forstås og realiseres i den enkelte barnehages pedagogiske praksis.

I IKOs høringsarbeid ble spørsmålet om fortolkingen av verdigrunnlaget tematisert, blant annet fordi rammeplanens kapittel om barnehagens verdigrunnlag ikke reflekterte hele verdiparagrafen, bare deler av den, og under andre tematiske overskrifter. Vi mente dette bidro til en utydeliggjøring av sammenhengen mellom lovbestemmelsene og forskriften, og presiserte det i vårt høringssvar. Denne utydeliggjøringen er gjennomgående for hele rammeplanen. I den endelige rammeplanteksten er §1 Barnehagens formål gjengitt i forskriften. Ellers i rammeplanen er barnehageloven relativt usynlig. Det fører til at det ikke går klart fram hvilke deler av barnehageloven som er tolket og utdypet, 
og hvilke bestemmelser som ikke er det, eller hvor vi finner sammenhengene mellom lov og forskrift.

Dette trekket ved rammeplanen gjør det svært tydelig at det blir en oppgave for barnehagelærerne å rette oppmerksomhet mot det rammeplanen ikke utdyper. Og samtidig som vi ser en utydelighet, er kanskje målformuleringene så retningsgivende at forpliktelsene virker styrende, og samtidig så åpne at de rommer god faglig skjønnsutøvelse. Da kan rammeplanen fungere som et godt arbeidsverktøy for profesjonsutøveren, og som styringsdokument for eieren.

Rammeplanen favner ikke alt, det bør den heller ikke gjøre. Derfor kan den heller ikke brukes som rettesnor for om man har gjort det man plikter. Barnehagens praksis er sammensatt og forsyner barnehagelæreren med et mangfold av tematikker, situasjoner, etiske problemstillinger og kompleksitet. Hvordan disse skal imøtegås i den pedagogiske praksisen er ikke mulig, heller ikke ønskelig, å favne i en forskrift. Det usynlige, det rammeplanen ikke sier noe om, er et stikkord når vi nå skal fortsette det videre arbeidet med implementering av rammeplanen i barnehagene. Rammeplanen sier for eksempel ikke noe om hvordan ivaretakelse av lek kan bygge på eller bidra til å fremme verdier som tilgivelse og solidaritet. Vi kan heller ikke lese direkte ut av rammeplanen hvordan arbeid med årsplan, planlegging, dokumentasjon og vurdering skal bygge på og utføres i forståelse med formålets grunnleggende verdier. Men i lys av kunnskap kan vi forstå og fortolke hvordan verdiene implisitt gjøres gjeldende i planen. Fortolkningsarbeidet må skje i de faglige fellesskapene, i barnehagene, og i barnehagelærerutdanningene. Vi kan kanskje forstå det slik at styrere og pedagogiske ledere er gitt i oppgave å gjøre verdiene gjeldende $\mathrm{i}$ arbeidet. De er også gitt ansvaret for at de ulike fagområdene settes i samspill med barnehagens arbeid med å ivareta behovene for omsorg og lek, og med å fremme læring og danning. Det må gjøres et arbeid lokalt i den enkelte barnehage for å se sammenhenger, integrere de ulike elementene, og definere hvordan verdiene skal gjøres gjeldende i det helhetlige arbeidet.

Et kjennetegn ved en profesjonsutøver er at den forhandler sitt mandat i lys av fagkunnskap. «Barnehagelærere er den profesjonen som utdannes spesielt for å kunne ivareta barnehagens oppgaver » står det på side 15 i rammeplanen. Pedagogisk leder er også gitt ansvar for å ivareta det pedagogiske arbeidet i tråd med godt faglig skjønn. Her ligger det også en mulighet for å lese inn en forståelse av at det er barnehagelærerne som i kraft av utdanningen er satt særlig i stand i å forstå, fortolke og forvalte barnehagens brede samfunnsmandat. 